\title{
Accelerated degradation of FADD and procaspase 8 in cells expressing human papilloma virus 16 E6 impairs TRAIL-mediated apoptosis
}

\author{
TO Garnett ${ }^{1}$, M Filippova ${ }^{1}$ and PJ Duerksen-Hughes ${ }^{\star, 1}$ \\ ${ }^{1}$ Department of Biochemistry and Microbiology, Center for Molecular Biology \\ and Gene Therapy, Loma Linda University School of Medicine, Loma Linda, \\ CA 92354, USA \\ * Corresponding author: PJ Duerksen-Hughes, Department of Biochemistry and \\ Microbiology, Center for Molecular Biology and Gene Therapy, 11085 Campus \\ Street, 121 Mortensen Hall, Loma Linda University School of Medicine, Lorna \\ Linda, CA 92354, USA. Tel: 909/558-4300 ext 81361; Fax: 909/558-0177; \\ E-mail: pdhughes@llu.edu
}

Received 26.9.05; revised 03.1.06; accepted 19.1.06; published online 10.3.06 Edited by JM Hardwick

\begin{abstract}
Viruses have developed sophisticated strategies to evade host defenses and facilitate the production and spread of progeny. In this study, we show that transfection of the human papillomavirus (HPV) 16 E6 oncogene into HCT116 cells provides protection from tumor necrosis factor-related apoptosis inducing ligand (TRAIL)-mediated apoptosis. Additionally, we demonstrate that the protection provided by $\mathrm{E} 6$ is dose-dependent because higher levels of $\mathrm{E} 6$ provide greater protection. The mechanism underlying this protection involves a rapid reduction in the protein levels of both Fasassociated death domain (FADD) and procaspase 8, which results in suppression of the activation of caspases 8, 3 and 2 . Interestingly, E6 does not interfere with the mitochondrial apoptotic pathway even though HCT116 cells have been classified as type II cells with regard to TRAIL signaling. These findings demonstrate that $\mathrm{E} 6$ has a more generalized effect on signaling by death ligands than was previously thought and support the notion that E6 can utilize p53independent mechanisms to modulate cell survival.

Cell Death and Differentiation (2006) 13, 1915-1926. doi:10.1038/sj.cdd.4401886; published online 10 March 2006
\end{abstract}

Keywords: TRAIL; HPV 16; E6; apoptosis; caspase activation

\footnotetext{
Abbreviations: HPV, human papillomavirus; TRAIL, tumor necrosis factor-related apoptosis inducing ligand; DR4, death receptor 4; DR5, death receptor 5; FADD, Fas-associated death domain; DD, death domain; DISC, death inducing signaling complex; Apaf-1, apoptosis protease activating factor 1; PARP, poly(ADP-ribose)polymerase; CHX, cycloheximide; MTT, 3-[4,5dimethylthiazol-2-yl]-2,5-diphenltetrazolium bromide; Z-VAD-FMK, Z-Val-Ala-Asp(OMe)-Flourmethylketone; DAPI, 4',6-diamidino-2phenylindole; dox, doxycycline; tet, tetracycline; GFP, green fluorescent protein; CMV, cytomegalovirus; HA, hemagglutinin; RT-PCR, reverse transcriptase-polymerase chain reaction; CFL1, cofilin 1
}

\section{Introduction}

The cytotoxic ligand Apo2L/tumor necrosis factor (TNF)related apoptosis inducing ligand (TRAIL) is a member of the TNF ligand family that has gained notoriety for its ability to selectively kill most cancer cells while sparing the majority of normal cells. ${ }^{1,2}$ TRAIL-induced apoptosis is initiated by the binding of TRAIL to death receptor (DR4) ${ }^{3}$ and/or death receptor 5 (DR5). ${ }^{4,5}$ TRAIL forms a homotrimer and associates with three receptor monomers. ${ }^{6}$ Homotypic, proteinprotein interactions between conserved death domains and death effector domains lead to the assembly of Fasassociated death domain (FADD) and procaspase(s) 8/10 molecules at the $\mathrm{C}$-terminus of the receptors to form the death inducing signaling complex (DISC). ${ }^{7,8}$ Activation of caspase(s) $8 / 10$ at the DISC is then followed by the activation of executioner caspases, such as caspases 3 and 7 , the cleavage of cellular substrates, and the loss of cell viability.

In addition to its potent anticancer properties, a growing body of evidence suggests that TRAIL may play an important role in host defense against viral infection. Notably, TRAIL is expressed on a variety of cells involved in host defense against viral infection including cytotoxic $\mathrm{T}$ cells, ${ }^{9,10}$ dendritic cells, ${ }^{11}$ monocytes/macrophages ${ }^{12}$ and natural killer (NK) cells. ${ }^{13,14}$

Not surprisingly, viruses have developed sophisticated strategies to both exploit TRAIL's potent cytotoxic properties, and to modulate cellular responses to TRAIL. For example, infection with human immunodeficiency virus-1 (HIV-1) can trigger the expression of TRAIL in monocytes, contributing to HIV-1 pathogenesis by inducing $\mathrm{CD} 4(+)$ T-cell death. ${ }^{15}$ Alternatively, viruses may block death receptor signaling by interfering with one or more components of the signaling pathway. Exogenous HIV-1 tat has been shown to protect cells from TRAIL-mediated apoptosis, ${ }^{16,17}$ as has the adenovirus E3-6.7K/10.4K/14.5K complex $^{18}$ and the human papillomavirus (HPV) 16 E5 protein. ${ }^{19}$ All of these viral proteins inhibit TRAIL-induced cell death by targeting the TRAIL signaling cascade.

The E6 oncoprotein of high-risk HPVs, such as HPV 16, plays a pivotal role in the pathophysiology of cervical cancer (reviewed in Mantovani and Banks ${ }^{20}$ and Longworth and Laimins ${ }^{21}$ ), which accounts for a large number of deaths among women worldwide. ${ }^{22,23}$ One of the primary targets of E6 is the tumor suppressor p53. ${ }^{24,25}$ It is well known that E6 binds to $p 53$ and mediates its degradation. However, E6 binds to a number of cellular targets other than p53, including proteins involved in apoptosis such as $\mathrm{Bak}^{26}$ and c-Myc. ${ }^{27}$ Furthermore, work by our lab has implicated E6 in the evasion of host-mediated apoptosis. We have shown that E6 protects cells from TNF-induced apoptosis by binding to the death domain (DD) of TNF R1 and preventing it from interacting with TNF R1-associated death domain (TRADD) ${ }^{28}$ In the case of Fas-mediated apoptosis, E6 inhibits signaling from Fas by 
binding to FADD and targeting it for degradation via the ubiquitin-proteasome pathway. ${ }^{29}$

The ability of E6 to abrogate TNF- and Fas-mediated apoptosis raised our interest in the possibility that E6 could also influence signaling by TRAIL because TNF, Fas and TRAIL utilize common mechanisms of signaling. There is evidence, however, that despite the similarities in the signaling pathways of these ligands, some cells that express E6 (e.g., SiHa) are resistant to TRAIL while others (e.g., CasKi) are sensitive. ${ }^{30}$ The $\mathrm{SiHa}$ and CasKi cell lines contain $1-2$ and $\sim 600$ copies of integrated HPV 16 per cell, ${ }^{31}$ respectively, and also express other HPV proteins, such as E5, which may influence cellular responses to TRAIL. ${ }^{19}$

In this study, we investigated whether HPV 16 E6 modulates cellular responses to TRAIL. As TRAIL-mediated apoptosis is not abrogated in all E6-expressing cells, we examined the influence of $\mathrm{E} 6$ alone (i.e., in the absence of other HPV proteins) on apoptotic signaling by TRAIL in a human epithelial, keratin-producing cell line (HCT116). We found that TRAIL-induced apoptosis is impaired in HCT116 cells stably expressing $\mathrm{E} 6$ by a mechanism involving the rapid degradation of both FADD and procaspase 8. Our findings provide additional evidence that E6 can modulate death receptor signaling by exploiting similarities in their signaling pathways.

\section{Results}

\section{Transfection of HPV 16 E6 into HCT116 cells provides protection from TRAIL-mediated cell death}

To investigate the possibility that E6 modulates cellular responses to TRAIL, we stably transfected HPV 16 E6, in the sense or antisense orientation, into HCT116 cells, an epithelial cell line that expresses keratin. To determine whether these cells were sensitive to TRAIL, we treated a pool of cells stably transfected with the antisense version of epitope-tagged hemagglutinin (HA)-E6 (HCT116E6ASP) with 5, 25 and $50 \mathrm{ng} / \mathrm{ml}$ of TRAIL in the presence or absence of the protein synthesis inhibitor cycloheximide ( $\mathrm{CHX})$. $\mathrm{CHX}$ was used in combination with TRAIL to potentiate its cytotoxicity because, like TNF, TRAIL can trigger a protective pathway in some cell types via the activation of NF- $\kappa \mathrm{B}$, whose targets include genes encoding intracellular inhibitors of apoptosis such as XIAP and c-FLIP. ${ }^{32}$ Treatment of HCT116E6ASP cells with TRAIL led to a decrease in cell viability in both the absence (24\%) and presence $(74 \%)$ of $\mathrm{CHX}$, providing evidence both that these cells are sensitive to TRAIL and that sensitization is potentiated by $\mathrm{CHX}$ (Figure 1a). Hence, $\mathrm{CHX}$ (see Materials and Methods for specific concentrations) was used in subsequent experiments to enhance cell killing by TRAIL.

To determine the effect of E6 on apoptotic signaling by TRAIL, stable pools expressing the sense or antisense versions of HA-E6 (HCT116E6SP and HCT116E6ASP, respectively) were treated with 25 and $50 \mathrm{ng} / \mathrm{ml}$ TRAIL. Interestingly, the sense pool was somewhat more resistant to TRAIL-mediated cell death than the antisense pool (Figure 1b). To further investigate this finding, individual clones from the sense pool were first selected and expanded, and then subjected to treatment with TRAIL. We found that clones expressing detectable levels of HA-E6S protein (HCT116E6S1 and S29) were significantly more resistant to TRAIL than clones in which HA-E6S expression could not be detected (e.g., S7), or untransfected parental cells (Figure 1c). For example, following exposure to $25 \mathrm{ng} / \mathrm{ml}$ TRAIL the percent viability of HCT116E6S1 and HCT116E6S29 cells was 66 and $81 \%$, respectively, compared to $29 \%$ for HCT116E6S7, and $43 \%$ for the parental cells (Figure 1c). As treatment with TRAIL was performed over a $16 \mathrm{~h}$ time span, we were also interested in determining how E6 affected cell viability at different time points during the treatment period. Therefore, we assessed the response of HCT116E6ASP and HCT116E6S29 cells to TRAIL $(50 \mathrm{ng} / \mathrm{ml})$ at $0,2,4,8$ and $16 \mathrm{~h}$. We observed a timedependent decrease in the viability of both HCT116E6ASP and HCT116E6S29 cells following exposure to TRAIL (Figure 1d). However, HCT116E6S29 cells were significantly more resistant to TRAIL than were the HCT116E6ASP cells at 4,8 and $16 \mathrm{~h}$.

We then examined the morphological features of TRAILinduced cell death in cells expressing the sense or antisense versions of HA-E6. This was accomplished by comparing the nuclei of these cells after 0 and $6 \mathrm{~h}$ of treatment with TRAIL, followed by fixing and staining with 4',6-diamidino-2-phenylindole (DAPI). Cells were considered nonviable (apoptotic) if they exhibited a loss of nuclear shape and/or nuclear fragmentation. Visualization of DAPI stained nuclei by fluorescence microscopy revealed considerable fragmentation of nuclei (20.5\%) from HA-E6AS-expressing cells at $6 \mathrm{~h}$ compared to much lower levels of nuclear fragmentation (7.9\%) from E6-expressing cells (Figure 2). Together, these findings clearly demonstrate that $\mathrm{E} 6$ can protect $\mathrm{HCT} 116$ cells from TRAIL-induced cell death.

\section{TRAIL-induced cell death in HCT116 cells occurs by apoptosis and is caspase-dependent}

The morphological analysis described above is consistent with an apoptotic form of cell death. To confirm that TRAIL triggers apoptosis in HCT116 cells under our conditions, the cells were treated with TRAIL for $0,3,6,9,12$ and $16 \mathrm{~h}$ and the lysates were analyzed for poly(ADP-ribose)polymerase (PARP) cleavage by immunoblot. PARP is a well-known substrate of the executioner caspases 3 and 7 and its cleavage pattern is a widely used marker of apoptotic cell death. ${ }^{33}$ As expected, we found that full-length PARP (116 kDa) was cleaved into an $89 \mathrm{kDa}$ protein $6-9 \mathrm{~h}$ following treatment with TRAIL, indicating that cell death occurred by apoptosis (Figure 3a). To determine whether TRAIL-induced apoptosis in HCT116 cells is caspase-dependent, the cells were treated with TRAIL or with a combination of TRAIL and the pan caspase inhibitor Z-Val-Ala-Asp(OMe)-Flourmethylketone (Z-VAD-FMK). Z-VAD-FMK provided significant protection from TRAIL-mediated apoptosis, indicating that cell death induced by TRAIL in HCT116 cells is caspase-dependent (Figure $3 b$ ). Both findings are thus consistent with previous reports that TRAIL induces apoptosis via a caspase-dependent mechanism in HCT116 cells. ${ }^{34,35}$ 

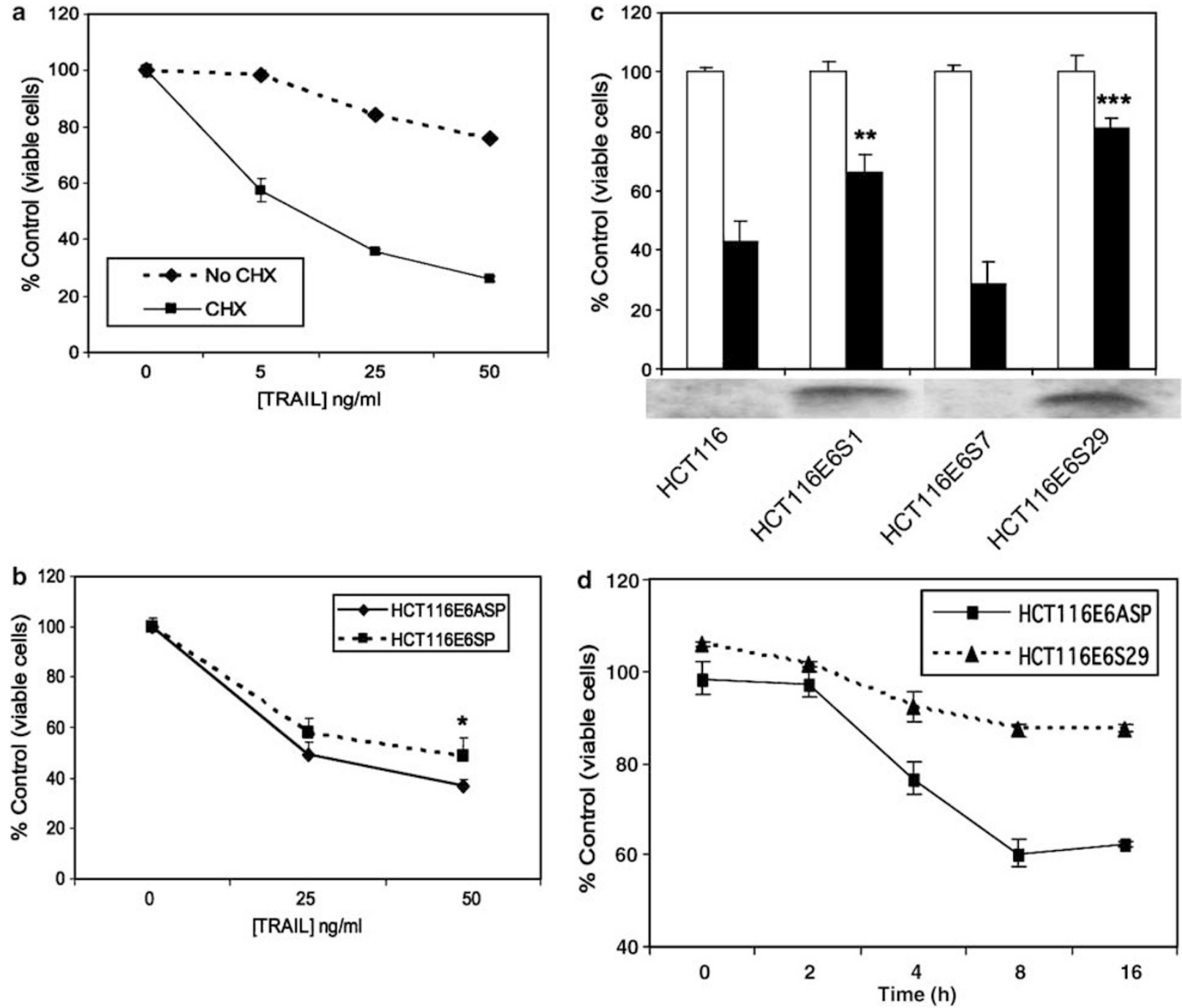

Figure 1 Transfection of E6 into HCT116 cells provides protection from TRAIL-induced apoptosis. HCT116 were transfected with either HA-E6S or HA-E6AS to create stable pools and clones. Parental cells as well as HA-E6S and HA-E6AS pools and clones were incubated with the indicated concentrations of TRAIL for $16 \mathrm{~h}$ in the presence of $\mathrm{CHX}$. After $16 \mathrm{~h}$, cell survival was measured by the MTT assay. Results of three independent experiments are shown, and the error bars represent the standard deviation. (a) The response of HCT116E6ASP (HA-E6AS pool) to 5, 25 and $50 \mathrm{ng} / \mathrm{ml}$ TRAlL alone or in the presence of CHX. (b) The response of HCT116E6ASP and HCT116E6SP (HA-E6S pool) to CHX plus 25 and $50 \mathrm{ng} / \mathrm{ml}$ TRAIL. ${ }^{*} P<0.05$ versus HCT116E6ASP cells treated with $50 \mathrm{ng} / \mathrm{ml}$ TRAlL. (c) Cell viability after treatment with $25 \mathrm{ng} / \mathrm{ml}$ TRAIL in the presence of $\mathrm{CHX}$, as well as HA-E6 levels, were determined for HCT116, HCT116E6S1, HCT116E6S7 and HCT116E6S29 cells by the MTT assay and immunoprecipitation, respectively. Immunoprecipitation of HA-E6 with anti-HA antibodies was performed on cell lysates from untreated cells. ${ }^{* *} P<0.01 ;{ }^{* \star *} P<0.001$ versus untransfected HCT116 cells treated with $25 \mathrm{ng} / \mathrm{ml}$ TRAlL. (d) Cell viability of HCT116E6ASP and HCT116E6S29 cells following treatment with $50 \mathrm{ng} / \mathrm{ml}$ TRAlL plus $\mathrm{CHX}$ for $0,2,4,8$ and $16 \mathrm{~h}$

\section{E6 protects HCT116 cells from TRAIL-induced apoptosis in a dose-dependent manner}

To more carefully examine the relationship between E6 expression and sensitivity to TRAIL, we created a cell line derived from HCT116 cells in which we could modulate the levels of HA-E6 based on the concentration of doxycycline (dox) in the media. Creation of the HCT116 E6-inducible cell line required two stable transfections. The first transfection was performed with a tetracycline (tet)/dox controlled transactivator (pTet-Off), and stable clones were selected and screened by transient transfection with a plasmid containing firefly luciferase under the control of the tet/dox response element (pTRE-luc). Of the stable clones isolated, clone \#3 (HCT116tet3) was found to have the lowest background expression of luciferase as well as the greatest induction of the reporter gene following dox treatment (Figure 4a). Based on this finding, the HCT116tet3 clone was selected for further experimentation and was then transfected with pTRE-HAE6S. Following the selection and expansion of individual clones, clones expressing HA-E6, as determined by immunoprecipitation/immunoblot, were selected. To confirm that HA-E6 gene expression could be modulated, messenger RNA from one of these clones, HCT116tet3E6S22, was subjected to reverse transcriptase-polymerase chain reaction (RT-PCR) analysis after incubation of HCT116tet3E6S22 cells in 

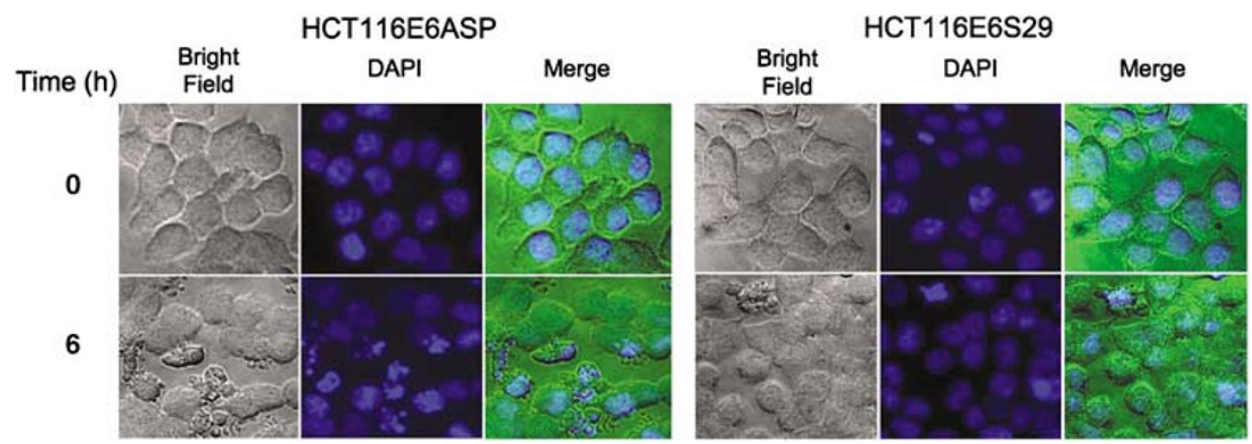

Figure 2 Morphology of E6-expressing HCT116 cells in response to TRAIL is consistent with protection from apoptosis. HCT116 cells expressing either the antisense (HCT116E6ASP) or sense (HCT116E6S29) version of E6 were seeded on coverslips in six-well plates and treated with TRAlL (50 ng/ml) plus CHX for 0 or $6 \mathrm{~h}$. After fixation in 4\% paraformaldehyde, the slips were mounted using Vectashield mounting media containing DAPI. Morphology of cells was analyzed by phase-contrast microscopy, and the DAPI-stained nuclei monitored using a UPA1FI objective. The cells in each panel were magnified $1000 \times$ with the oil immersion lens. For each set of three panels, the left represents phase contrast microscopy, the middle the DAPI staining pattern, and the right a merged image. The green background in the merged image is due to the light used to obtain a visible image

a

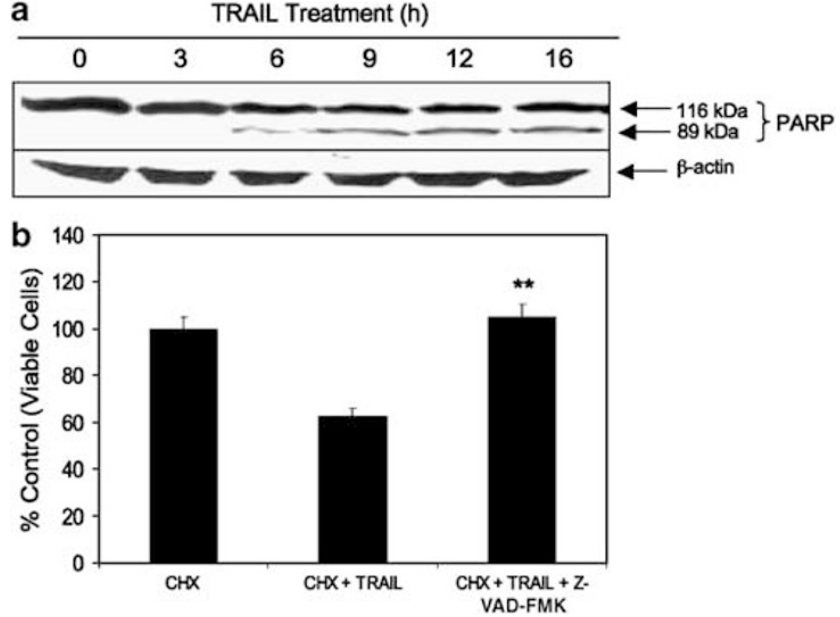

Figure 3 Cell death triggered by TRAIL in HCT116 cells occurs by apoptosis and is caspase dependent. (a) HCT116 cells were treated with TRAIL $(50 \mathrm{ng} / \mathrm{ml})$ in combination with $\mathrm{CHX}$ at the indicated time points and then lysed. Afterward, the lysates were analyzed for PARP cleavage by immunoblot. (b) HCT116 cells were treated with $\mathrm{CHX}$ alone or the indicated combinations of $\mathrm{CHX}$, TRAIL $(50 \mathrm{ng} / \mathrm{ml})$ and Z-VAD-FMK $(50 \mu \mathrm{M})$ for $16 \mathrm{~h}$. After $16 \mathrm{~h}$, the percentage of viable cells was determined by the MTT assay. For B, results of three independent experiments are shown, and the error bars represent the standard deviation. ${ }^{*} P<0.01$ versus $\mathrm{HCT} 116$ cells treated with $\mathrm{CHX}$ and TRAIL alone

different concentrations of dox. As expected, HA-E6 mRNA levels were modulated by dox in the Tet-Off cell line (Figure 4b). We then treated HCT116tetE6S22 cells with TRAIL in the presence of different concentrations of dox to determine the effect of varying the levels of HA-E6 on cell viability. We found that in the presence of maximal levels of HA-E6 (no dox), the cells experienced significant protection from TRAIL as compared to cells lacking E6 (HCT116tet3) (Figure 4c). Following the downregulation of HA-E6 by increasing the amount of dox added to the media, HCT116tetE6S22 cells became more sensitive to TRAIL (Figure 4c). These findings demonstrate that $\mathrm{E} 6$ can modulate TRAIL-mediated apoptosis in a dose-dependent fashion.

\section{E6 acts upstream of the mitochondrial apoptotic pathway in HCT116 cells}

The TRAIL cell death pathway is believed to follow a model similar to the type I/type II system described for Fas. ${ }^{34}$ According to this model, DISC formation in type I cells is robust and caspase 8 directly cleaves caspase 3 . However, in type II cells, DISC formation is weak, and caspase 8 cleaves Bid leading to the amplification of apoptotic signals from TRAIL via the mitochondrial pathway. El-Deiry and coworkers have suggested that HCT116 cells behave like type II cells. ${ }^{34}$ Thus, it was of interest to determine whether the inhibitory effect of E6 on apoptotic signal transduction by TRAIL, and the resulting survival of HCT116 cells, was due to its influence on the mitochondrial apoptotic pathway.

To activate the mitochondrial pathway, E6-expressing (HCT116E6S1 and HCT116E6S29) and control (HCT116E6ASP) cells were treated with different concentrations of the DNA damaging agent mitomycin $\mathrm{C}$ or with ceramide for $24 \mathrm{~h}$. Following the treatment period, the percentage of surviving cells was determined by the 3-[4,5dimethylthiazol-2-yl]-2,5-diphenltetrazolium bromide (MTT) assay. We found no difference in the sensitivity of E6expressing and control HCT116 cells to either mitomycin C or ceramide (Figure $5 a$ and $b$ ). We also examined the levels of Apaf-1 (apoptosis protease activating factor 1 ) in cells expressing or not expressing HA-E6S at $0,12,24$ and $36 \mathrm{~h}$ after incubation with a low dose of mitomycin C $(2 \mu \mathrm{g} / \mathrm{ml})$. Apaf-1 $(\sim 130 \mathrm{kDa})$ is a key component of the apoptosome, which is formed shortly after mitochondrial depolarization. In the apoptosome, Apaf-1 associates with cytochrome $c$ and procaspase 9 leading to the activation of caspase 9 and downstream executioner caspases. We observed an elevation in Apaf-1 levels at $12 \mathrm{~h}$ in both HA-E6S-expressing and nonexpressing cells followed by a gradual decrease to basal levels at 24 and $36 \mathrm{~h}$ (Figure $5 \mathrm{c}$ ). We then reprobed the membrane with anti-p53 antibodies to assess p53 levels in the two cell lines and found higher basal and induced levels of p53 in the HCT116E6ASP cells than in the HCT116E6S29 cells (Figure 5c), consistent with the known function of E6 in targeting p53 for degradation. 
a

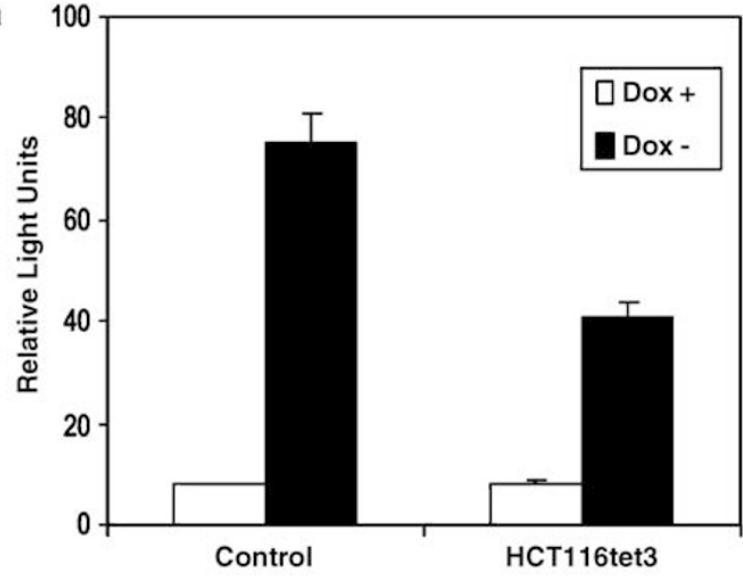

b
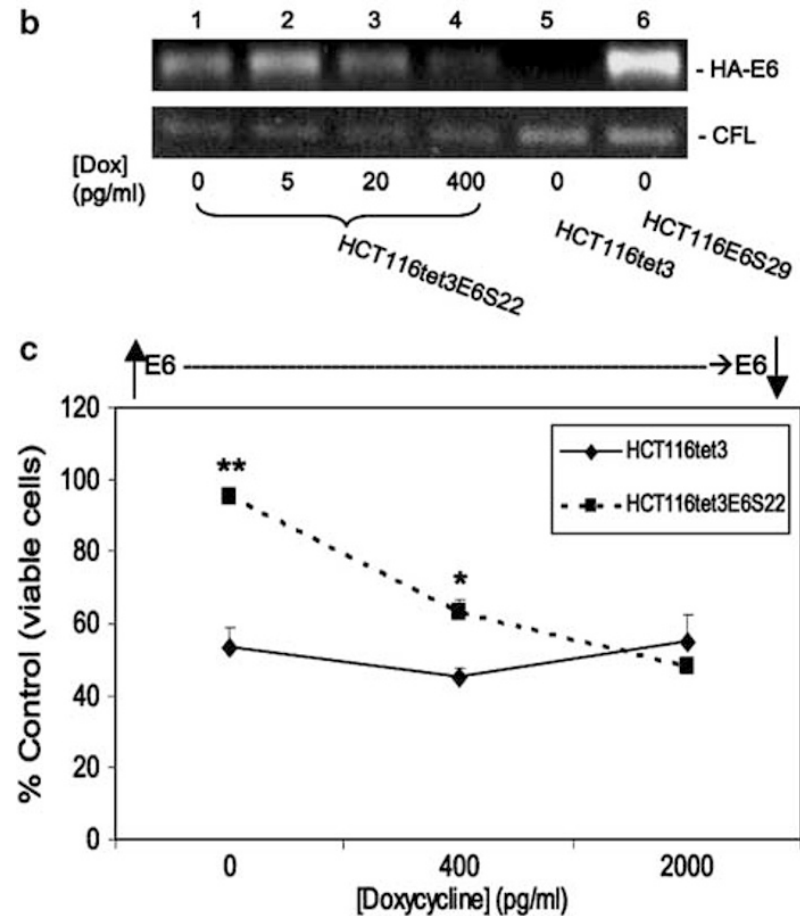

Figure 4 Modulation of HA-E6 levels alters the sensitivity of HCT116 cells to TRAIL. (a) Parental HCT116 cells were transiently co-transfected with pTet-Off and pTRE-luc constructs (control) while HCT116tet3 cells (parental HCT116 cells stably expressing the pTet-Off plasmid) were transiently transfected with pTREluc alone. The cells were then treated or untreated with doxycycline $(1000 \mathrm{pg} / \mathrm{ml})$ and the level of luciferase expressed was measured by a luminometer according to the manufacturer's instructions. Results of three independent experiments are shown, and the error bars represent the standard deviation. (b) RT-PCR analysis of HA-E6 mRNA levels in HCT116tet3 cells (lane 5), HCT116E6S29 cells (lane 6) and HCT116tet3E6S22 cells (lanes 1-4: 0, 5, 20 and $400 \mathrm{pg} / \mathrm{ml}$ doxycycline, respectively). Cofilin (CFL) levels were also measured and served as a loading control. (c) Response of control cells (HCT116tet3-HCT116 cells stably expressing the pTet-Off plasmid but not expressing E6) and HCT116tet3E6S22 cells (expressing E6) to TRAIL $(50 \mathrm{ng} / \mathrm{ml})$. Cells were cultured in the indicated concentration of doxycycline and then treated with TRAIL for $16 \mathrm{~h}$ in the presence of CHX. After $16 \mathrm{~h}$, the percentage of viable cells was determined by the MTT assay. Results of three independent experiments are shown, and the error bars represent the standard deviation. ${ }^{\star} P<0.05 ;{ }^{* \star} P<0.01$ versus HCT116tet 3 cells treated with the corresponding concentrations of doxycycline

In light of these findings we concluded that while the expression of E6 in type II HCT116 cells causes resistance to TRAIL-mediated apoptosis (Figure $1 \mathrm{~b}$ and c; Figure 2), cell
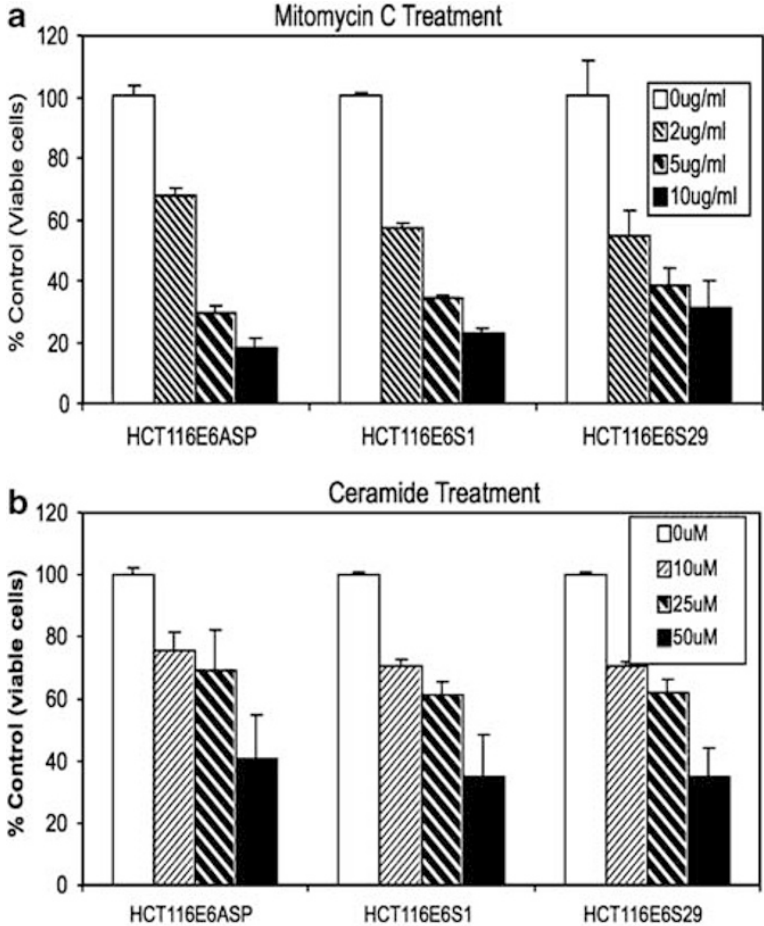

C

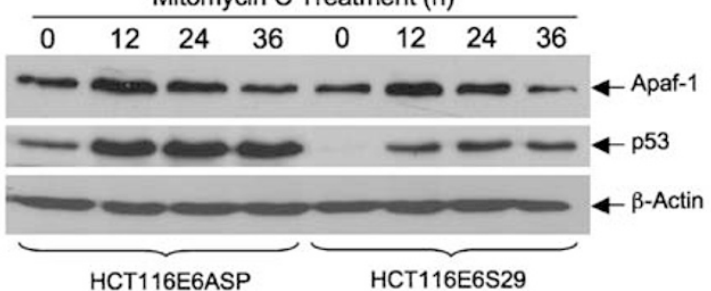

Figure 5 E6-mediated resistance of HCT116 cells to TRAIL occurs upstream of the mitochondrial apoptotic pathway. HCT116 cells stably expressing HA-E6AS and HA-E6S were treated with the indicated concentrations of mitomycin $\mathrm{C}(\mathrm{a})$ and ceramide (b) for $24 \mathrm{~h}$. After $24 \mathrm{~h}$, cell survival was measured by the MTT assay. Results of three independent experiments are shown, and the error bars represent the standard deviation. (c) HCT116E6ASP and HCT116E6S29 cells were analyzed for Apaf-1 $\sim 130 \mathrm{kDa}$ ) and p53 levels by immunoblot following treatment with mitomycin C $(2 \mu \mathrm{g} / \mathrm{ml})$ for the indicated hours. $\beta$-actin served as a loading control

death induced by known activators of the mitochondrial apoptotic pathway is not blocked in these cells. Therefore, these data suggest that E6 inhibits TRAIL-mediated apoptosis upstream of the mitochondrial apoptotic pathway, but do not entirely rule out an effect on the mitochondria.

\section{FADD is necessary for TRAIL-mediated apoptosis in HCT116 cells and is rapidly degraded in cells stably expressing $\mathrm{E} 6$}

The binding of TRAIL to death receptor 4 (DR4) and DR5 results in the formation of the TRAIL DISC, which contains key signaling molecules required for transmitting apoptotic signals from TRAIL to executioner caspases that carry out the cell death program. ${ }^{32}$ It is well established that both FADD and procaspase 8 are recruited to the TRAIL DISC and are necessary for TRAIL-induced apoptosis in most cell types. ${ }^{7,8}$ 
To assess the importance of FADD in the TRAIL cell death pathway in HCT116 cells, we first determined whether FADD expression could be suppressed by post-transcriptional gene silencing using siRNA directed against FADD. As endogenous levels of FADD in HCT116 cells are low, FADD protein analysis in this and subsequent experiments was performed with transfected FADD (pcDNA3-FADD). First, HCT116 cells were transiently transfected with either nonspecific siRNA (siControl) or siRNA targeting FADD (siFADD), followed by pcDNA3-FADD $24 \mathrm{~h}$ later. To measure the transfection efficiency of pcDNA3-FADD under these conditions, the cells were also co-transfected with a plasmid coding for green fluorescence protein (GFP) ( $p E-1$ cytomegalovirus (CMV)GFP). Subsequently, the cells were lysed and level of FADD and GFP in the lysates was analyzed by immunoblot. As expected, siFADD but not siControl significantly inhibited FADD expression (Figure 6a). We once again transiently transfected HCT116 cells with siControl or siFADD. Following transfection, the cells were treated with TRAIL and TNF. TNF was included in the experiment because FADD is also considered to be an important component of the signaling pathways induced by this ligand, and thus TNF served as a positive control. The cells were then analyzed by the MTT assay to determine the number of surviving cells. The results demonstrate that both TRAIL- and TNF-mediated apoptosis was significantly impaired by siFADD (Figure 6b), which suggests that FADD plays an important role in apoptotic signaling by TRAIL in HCT116 cells.

To determine whether E6 impairs TRAIL-mediated apoptosis in HCT116 cells by undermining the stability of FADD, we examined FADD protein levels in cells expressing the sense or antisense versions of HA-E6. HCT116 cells expressing HAE6S (HCT116E6S29) and HA-E6AS (HCT116E6ASP) were treated with $\mathrm{CHX}$ for $0,2,4,8$ and $16 \mathrm{~h}$ to suppress de novo protein synthesis and then lysed. Subsequently, the lysates were subjected to immunoblot to examine any changes in the levels of FADD. We observed a significant decrease in the levels of FADD (particularly at 8 and $16 \mathrm{~h}$ ) in the HCT116 HAE6S cells compared to a very small decrease in the HCT116 HA-E6ASP cells (Figure 6c).

Collectively, these findings suggest that E6 inhibits TRAILinduced apoptosis in HCT116 cells, at least in part, by mediating the rapid degradation of FADD. This is entirely consistent with our previous observation that the impairment of Fas-mediated apoptosis in E6-expressing U2OS cells results from the targeted degradation of FADD, ${ }^{29}$ and our results demonstrate that there is a substantial reduction in the levels of transfected FADD in the presence of E6.

\section{E6 suppresses the activation of caspases 8,3 and 2 in HCT116 cells by accelerating the degradation of procaspase 8}

To further explore the mechanism by which E6 inhibits TRAILinduced apoptosis in HCT116 cells, we examined the effect of E6 on caspase activation in the extrinsic cell death pathway. HCT116 cells stably expressing HA-E6S (HCT116E6S29) and HA-E6AS (HCT116E6ASP) were treated with TRAIL at intervals of $2-3 \mathrm{~h}$ and then lysed. Subsequently, the lysates
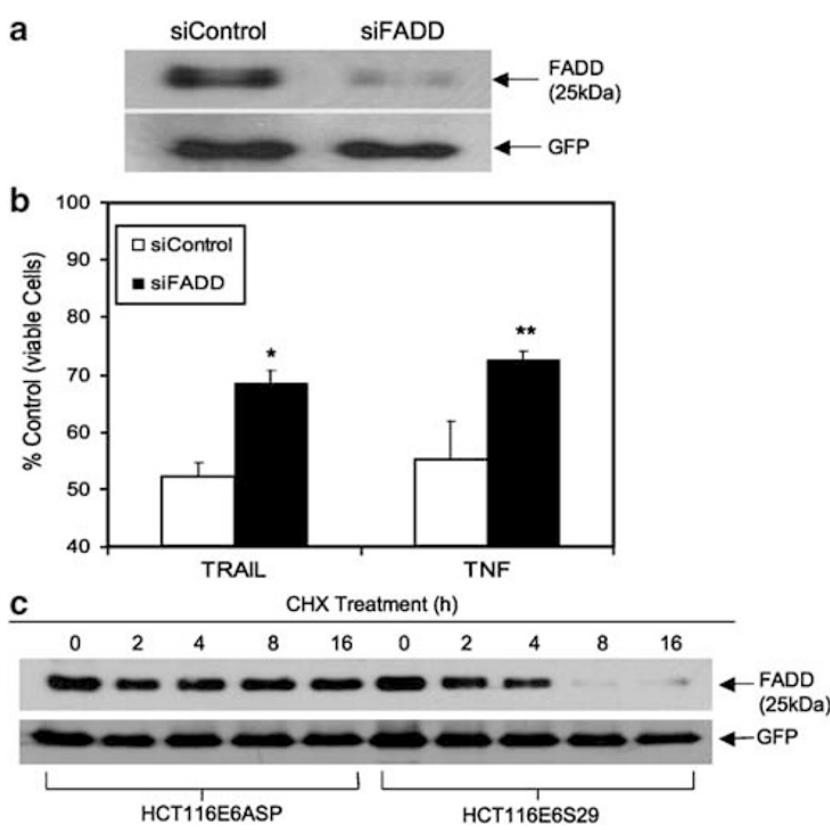

Figure 6 FADD is required for TRAIL-triggered apoptosis and its degradation is accelerated in HCT116 cells harboring E6. (a and $\mathbf{b})$ FADD is required for TRAILmediated apoptosis in HCT116 cells. (a) siFADD inhibits FADD expression. Parental HCT116 cells were transfected with siControl and SiFADD as previously described. After $24 \mathrm{~h}$, the cells were transfected with pcDNA3-FADD and $\mathrm{pE}$ $1 C M V-G F P$ and incubated for an additional $24 \mathrm{~h}$. The cells were then lysed, and the lysates were analyzed for the expression of FADD and GFP by immunoblot using anti-FADD and anti-GFP antibodies. (b) Silencing FADD expression via RNA interference protects HCT116 cells from TNF- and TRAIL-mediated apoptosis. Parental HCT116 cells were either transfected with nonspecific, control siRNA (siControl) or siFADD and incubated at $37^{\circ} \mathrm{C}$ for $24 \mathrm{~h}$. Following incubation, the cells were treated with TNF $(5 \mathrm{ng} / \mathrm{ml})$ or TRAIL $(50 \mathrm{ng} / \mathrm{ml})$ in the presence of $\mathrm{CHX}$ for $16 \mathrm{~h}$. After $16 \mathrm{~h}$, cell survival was measured by the MTT assay. Results of three independent experiments are shown, and the error bars represent the standard deviation. ${ }^{*} P<0.05$; ${ }^{\star *} P<0.01$ versus the corresponding siControl transfected cells. (c) FADD is rapidly degraded in E6-expressing HCT116 cells. HCT116E6ASP and HCT116E6S29 were transfected with pcDNA3-FADD and pE-1CMV-GFP for $24 \mathrm{~h}$. After $24 \mathrm{~h}$, cells were untreated or treated with $\mathrm{CHX}$ at the indicated time points and then lysed. The levels of FADD and GFP in the untreated and treated lysates were then analyzed by immunoblot using anti-FADD and anti-GFP antibodies

were analyzed for caspase 8 and 3 activity using the appropriate flourogenic substrates (see Materials and Methods) in the presence and absence of inhibitors of each caspase. We also analyzed the activity of caspase 2 because it was recently reported that this initiator caspase is involved in TRAIL-mediated apoptosis in HCT116 cells. $^{36}$ In cells expressing the HA-E6AS, caspase 8 activation occurred soon after TRAIL treatment with a maximum level observed between 2 and $4 \mathrm{~h}$, while caspase 3 activation began to increase at about $4 \mathrm{~h}$ and continued to rise at $6 \mathrm{~h}$ (Figure $7 \mathrm{a}$ ). However, in the cells expressing HA-E6S, the activation of caspases 8 and 3 was reduced to less than half of peak levels. Interestingly, the activation of caspase 2 in the control cells (HCT116E6ASP) was robust following TRAIL treatment, but was almost completely inhibited in the cells expressing HA-E6S (Figure 7a). These results are consistent with our previous finding of E6-mediated FADD degradation, in that they support the notion that E6 targets the TRAIL pathway upstream of the caspase cascade. 

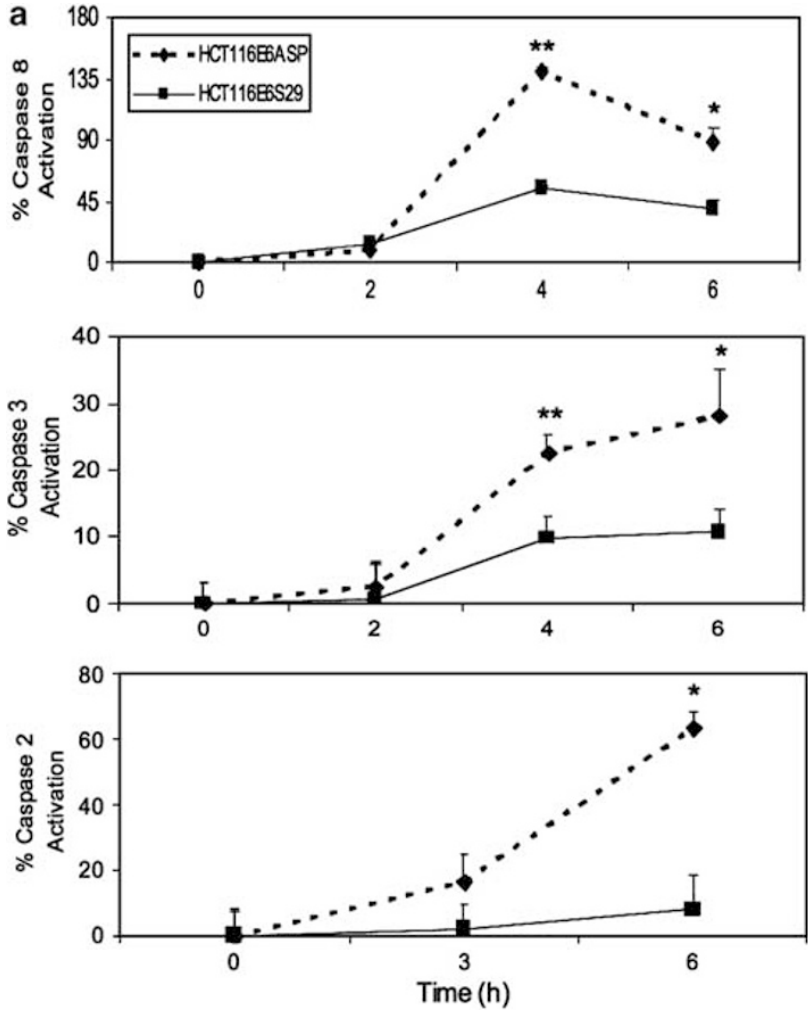

b
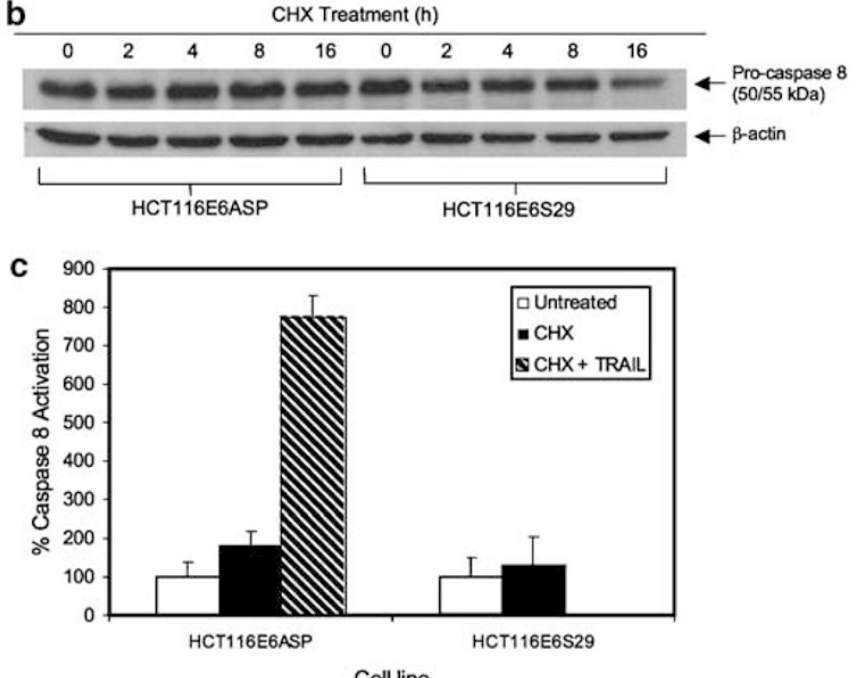

d

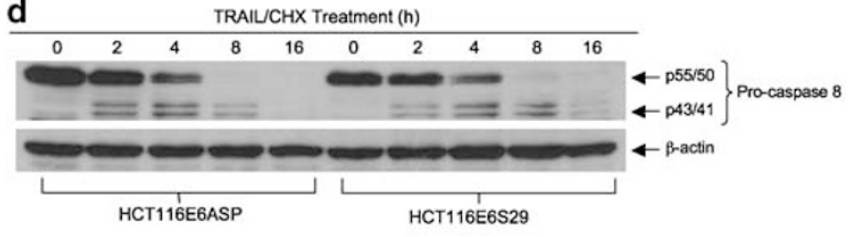

Figure 7 The activation of caspases 8,3 and 2 is attenuated in E6-expressing HCT116 cells due to the rapid degradation of procaspase 8 . (a) The activation of caspases 8,3 and 2 by TRAlL is suppressed in E6-expressing HCT116 cells. HCT116 cells stably expressing HA-E6AS (HCT116E6ASP) and HA-E6S (HCT116E6S29) were treated with TRAIL $(50 \mathrm{ng} / \mathrm{ml})$ in combination with $\mathrm{CHX}$ for indicated time intervals and then lysed. Afterward, the lysates were incubated with flourogenic substrates for capases 8 (Ac-IETD-pNA), 3 (Ac-DEVD-AMC) and 2 (Ac-VDVAD-AMC) in the presence or absence of the appropriate capase inhibitor (Ac-IETD-CHO, Ac-DEVD$\mathrm{CHO}$ and $\mathrm{Ac}-\mathrm{VDVAD}-\mathrm{CHO}$, respectively). The released fluorochrome was measured with a fluorimeter. Percent caspase activity was calculated by subtracting the activity in wells containing inhibitor from the activity in wells lacking inhibitor and expressing this number as a percentage of caspase activity in wells containing untreated HCT116E6ASP cells. (b) The degradation of procaspase 8 is accelerated in E6-expressing HCT116 cells. HCT116E6ASP, HCT116E6S29 cells were untreated or treated with $\mathrm{CHX}$ at the indicated time points and then lysed. The levels of procaspase 8 and $\beta$-actin were then analyzed by immunoblot using anticapase 8 and anti- $\beta$ actin antibodies. Monoclonal anticaspase 8 antibodies (BD Pharmingen) recognize the proform of human caspase 8, which migrates as a 50/55 kDa doublet, as well as the cleaved forms $(46 / 36$ and $23 \mathrm{kDa})$. (c) The reduction in procaspase 8 levels following $\mathrm{CHX}$ treatment is not due to its activation. The activation of caspase 8 in untreated or CHX-treated HCT116E6ASP and HCT116E6S29 cells was determined as described in (a). HCT116E6ASP cells treated with both CHX and TRAlL (50 ng/ $\mathrm{ml}$ ) served as a positive control. (d) The cleavage of procaspase 8 is delayed in the presence of E6. HCT116E6ASP and HCT116E6S29 cells were treated with TRAlL $(50 \mathrm{ng} / \mathrm{ml})$ and $\mathrm{CHX}$ for $0,2,4,8$ and $16 \mathrm{~h}$. The cells were then lysed and the levels of procaspase 8 and $\beta$-actin were analyzed by immunoblot using anticapase 8 (Alexis Biochemicals) and anti- $\beta$-actin antibodies

To determine whether E6 suppresses caspase activation by undermining the stability of procaspase 8 and thus contributing to cellular resistance to TRAIL-mediated apoptosis, we examined procaspase 8 protein levels in cells expressing either the sense or antisense versions of HA-E6. As described above, HCT116 cells expressing HA-E6S (HCT116E6S1 or S29) and HA-E6AS (HCT116E6ASP) were treated with $\mathrm{CHX}$ for $0,2,4,8$ and $16 \mathrm{~h}$ to suppress de novo protein synthesis and then lysed. Subsequently, the lysates were subjected to immunoblot to examine any changes in the levels of procaspase 8 . The levels of $\beta$-actin were also analyzed and served as a loading control. We observed a gradual, but significant decrease in the levels of procaspase 8 in the HCT116 HA-E6S cells compared to virtually no change in the HCT116E6ASP cells (Figure 7b). The decrease in procaspase 8 levels was not due to its activation because the cleaved forms of the proenzyme (p40/36 and p23) were not detected. Additionally, when HCT116E6ASP cells and HCT116E6S29 cells were untreated or treated with $\mathrm{CHX}$ for
$4 \mathrm{~h}$, and then subjected to the flourometric caspase activity assay described above, there was no significant change in the activation of caspase 8 in either cell line (Figure 7c). However, there was a large increase in the activity of caspase 8 in HCT116E6ASP cells treated with $\mathrm{CHX}$ and TRAIL, which served as a positive control (Figure 7c).

We also examined the protein expression of procaspase 8 in HCT116E6ASP and HCT116E6S29 cells under conditions where the cells were treated with TRAIL as well as $\mathrm{CHX}$. In this experiment, cells were treated with TRAIL/CHX for $0,2,4$, 8 and $16 \mathrm{~h}$, lysed and then subjected to immunoblot analysis with anticaspase 8 and anti- $\beta$-actin antibodies. The expression of the p55/50 subunit of procaspase 8 was higher in HCT116E6ASP cells than in HCT116E6S29 cells at $0 \mathrm{~h}$ (untreated). This is consistent with the previous observation that procaspase 8 is rapidly degraded in the presence of E6. From 2 to $16 \mathrm{~h}$, there was a precipitous decline in the levels of the p55/50 subunit in both cell lines accompanied by the appearance of the p43/41 cleavage product (Figure $7 d$ ). This 
was expected since TRAIL treatment leads to the activation and cleavage of procaspase 8 . However, while the level of the p43/41 cleavage product increased and then decreased in both HCT116E6ASP and HCT116E6S29 cells over time, this change occurred earlier in the HCT116E6ASP cells than in the HCT116E6S29 cells (Figure 7d). Therefore, we concluded that during the period of time when HCT116E6S29 cells are resistant to TRAIL (Figure 1d) the cleavage of procaspase 8 is delayed.

Together, these data provide substantive evidence that E6 protects HCT116 cells from TRAIL by accelerating the degradation and delaying the cleavage of procaspase 8 , and demonstrate that E6 short-circuits the TRAIL signaling pathway in HCT116 cells by targeting two of its essential components, FADD and procaspase 8.

\section{Discussion}

Viruses have developed sophisticated ways to evade immune surveillance by the host and to facilitate the production and spread of progeny. ${ }^{37}$ One of the primary ways viruses avoid elimination is by protecting infected cells from host-mediated apoptosis. Viruses employ several strategies to inhibit apoptosis of infected cells including modulating ligand expression, inhibiting ligand-receptor interactions, interfering with the DISC, suppressing caspase activation, and targeting the mitochondria. ${ }^{38}$ For example, adenovirus EIB-19K, a Bcl2 type protein, inhibits TNF-induced apoptosis by suppressing mitochondrial activation, ${ }^{39,40}$ while the E3-10.4/14.5/6.7 proteins inhibit TRAIL-mediated apoptosis by decreasing the expression of DR4 and DR5 on the cell surface. ${ }^{18}$ Bovine herpes virus-4 BORFE2 and equine herpes virus E8 prevent TNF and Fas-induced apoptosis by interfering with caspase $8^{41,42}$ while CMV abrogates TNF, FasL and TRAIL-mediated apoptosis by suppressing the activation of caspase $8 .{ }^{43}$

Our results provide substantive evidence that HPV 16 E6 targets procaspase 8 in order to block the transmission of apoptotic signals from TRAIL. Co-immunoprecipitation and mammalian two-hybrid experiments performed in our lab demonstrate that procaspase 8 interacts with E6 and inhibiting the proteosome can prevent its degradation in E6expressing cells (manuscript submitted). Since the activation of caspase 8 initiates the caspase cascade, a reduction in the stability of procaspase 8 will affect sequential events in the pathway. Therefore, the suppression of caspase 8,3 and 2 activation in E6-expressing HCT116 cells appears to be a consequence of the ability of E6 to decrease the levels of procaspase 8 by targeting it for degradation. These findings suggest that like FADD, procaspase 8 warrants recognition as a novel target of E6. However, it should be noted that the interaction of E6 with FADD, and its putative interaction with procaspase 8 does not imply that E6 lacks specificity because we have been unable to demonstrate statistically significant binding between $\mathrm{E} 6$ and TRADD $^{29}$ or between $\mathrm{E} 6$ and Fas (unpublished data).

Another novel finding of our study is that E6 inhibits TRAILinduced activation of caspase 2 in HCT116 cells. This finding is consistent with a recent report by Wagner et al. ${ }^{36}$ showing that caspase 2 plays a role in TRAIL-induced apoptosis. In this report, caspase 2 was found to act upstream of Bid cleavage and to be necessary for TRAIL-mediated apoptosis in HCT116 cells but not HeLa cells. Our results also suggest that caspase 2 activation occurs after the activation of caspase 8 but before the activation of the mitochondrial pathway. A number of studies have found that caspase 3 can directly activate caspase $2,{ }^{44,45}$ which has led some investigators to conclude that caspase 2 can function downstream of the mitochondria. On the contrary, other studies have implicated caspase 2 in the activation of the mitochondrial pathway, either directly or indirectly by facilitating the cleavage of Bid. ${ }^{46-48}$ In our study, E6 did not interfere with the mitochondrial apoptotic pathway in HCT116 cells, though the activation of caspase 2 was strongly suppressed in E6expressing cells. This observation bolsters the notion that caspase 2 acts upstream of the mitochondria in TRAILmediated cell death in HCT116 cells and strengthens our conclusion that E6 targets apical events in the TRAIL pathway in these cells.

Given that some E6-expressing cells (e.g., SiHa) are resistant to TRAIL while others (e.g., CasKi) are not, ${ }^{30}$ we examined the influence of E6 on apoptotic signaling by TRAIL in a cellular model lacking other HPV proteins, such as E5, which can also interfere with the pathway. The E5 protein has been shown to protect cells from both Fas and TRAILmediated apoptosis, albeit by different mechanisms. ${ }^{19}$ In their study, Kabsch and Alonso showed that E5 inhibits Fasinduced apoptosis, in part, by decreasing the cell surface expression of the Fas receptor. While E5 did not downregulate TRAIL receptor expression, it was found to inhibit TRAIL signaling by interfering with the formation of the TRAIL DISC and thereby inhibiting the cleavage of procaspases 8 and 3, as well as of PARP. Given that E5 possesses weak transforming activity $^{49}$ and is most abundant before the integration of the HPV 16 genome into the host DNA, ${ }^{50}$ it may be important in the early stages of viral infection to create the conditions conducive for viral propagation. In contrast, E6 is highly oncogenic and appears to perform the majority of its functions postintegration, both in immune evasion and in tumorigenesis, and while E6 binds to several proteins involved in apoptosis, ${ }^{26-29}$ no such interaction has been demonstrated for E5.

Interestingly, we found that while transfection of E6 into HCT116 cells inhibits TRAIL-induced apoptosis, it did not prevent cell death induced by TRAIL in all the human cell lines that were tested (data not shown). For example, we observed that E6-expressing clones derived from U2OS osteosarcoma cells were sensitive to TRAIL despite containing relatively high levels of E6. This is consistent with the previous observation regarding the response of $\mathrm{SiHa}$ and CasKi cells to TRAIL. One possible explanation for the difference in the response of E6expressing HCT116 and U2OS cells to TRAIL may be that distinctive cellular characteristics predispose some cell types, but not others, to the antiapoptotic actions of E6. Following a similar line of reasoning, it is also likely that cell-type specific differences in the TRAIL pathway influence the ability of E6 to block apoptosis and this raises the intriguing possibility that TRAIL may utilize different signaling mechanisms in a manner dependant on the cellular context.

The ability of E6 to mediate the degradation of p53 is well established in the literature and it is widely accepted that this 
phenomenon contributes to tumorigenesis by altering cell survival. $^{20,21}$ This study further elucidates the mechanisms employed by E6 to modulate cellular responses to death stimuli. Cell death induced by TNF, Fas and TRAIL is transmitted through FADD and caspase 8 from cell surface receptors, to executioner caspases. By undermining the stability of these important signaling molecules at the apex of the cascade, E6 is able to alter cell survival in a p53independent manner, which may further contribute to tumorigenesis. Thus, HPV 16 appears to employ both p53dependent and -independent strategies to evade host defenses and avoid elimination by the immune system.

\section{Materials and Methods}

\section{Reagents}

Lyophilized human recombinant Apo2L/TRAIL (Peprotech Inc., Rock Hill, NJ, USA) and TNF (R\&D Systems, Minneapolis, MN, USA) were dissolved in phosphate-buffered saline (PBS) to yield 100 and $1 \mu \mathrm{g} / \mathrm{ml}$ stocks, respectively; CHX (Sigma, St Louis, MO, USA) was prepared as a $5 \mathrm{mg} / \mathrm{ml}$ stock; $\mathrm{C}_{2}$-Ceramide (Biomol, Plymouth Meeting, PA, USA) was dissolved in dimethyl sulfoxide (DMSO) to yield a $25 \mathrm{mM}$ stock; dox (Clontech, Palo Alto, CA, USA) was dissolved in PBS to yield a $1 \mathrm{mg} / \mathrm{ml}$ stock; and Z-VADFMK (Biomol) was dissolved in DMSO to yield a $10 \mathrm{mM}$ stock solution. Each of these reagents were aliquoted and stored at $20^{\circ} \mathrm{C}$ before use. 3-[4,5-Dimethylthiazol-2-yl]-2,5-diphenyltetrazolium bromide (MTT) (Sig$\mathrm{ma}$ ) was dissolved in PBS, and mitomycin C (Roche Molecular Biochemicals, Indianapolis, IN, USA) was dissolved in DMSO to yield stock concentrations of $5 \mathrm{mg} / \mathrm{ml}$, which were stored at $4^{\circ} \mathrm{C}$ until use.

Monoclonal antibodies directed against $\beta$-actin and $\mathrm{HA}$ (Roche Molecular Biochemicals) were dissolved in PBS to yield $400 \mu \mathrm{g} / \mathrm{ml}$ stock solutions and stored at $-20^{\circ} \mathrm{C}$ before use. The mouse monoclonal, rabbit polyclonal and rat polyclonal peroxidase-coupled anti-HA antibodies (Roche Molecular Biochemicals) were stored under the same conditions before use. Other antibodies used included antibodies directed against Apaf-1, (BD Pharmingen), caspase 8 (BD Pharmingen and Alexis Biochemicals), GFP (Roche Molecular Biochemicals), PARP (Calbiochem) and p53 (Novocastra Laboratories, Ltd, Newcastle, UK). These antibodies were stored at $4^{\circ} \mathrm{C}$ until use.

\section{Cell culture}

HCT116 (human colon carcinoma) cells were obtained from the ATCC (Manassas, VA, USA) and were cultured in McCoy's 5A medium (Invitrogen, Carlsbad, CA, USA) supplemented with $10 \%$ fetal bovine serum (Invitrogen), penicillin $(100 \mathrm{U} / \mathrm{ml})$, and streptomycin $(100 \mu \mathrm{g} / \mathrm{ml})$ (Sigma).

\section{Plasmids}

The pHA-E6S and pHA-E6AS plasmids have been described previously, ${ }^{29}$ and, respectively, contain either the sense or the antisense versions of epitope-tagged E6 (HA-E6) under the control of the CMV promoter. The following plasmids were obtained from and described in the Tet-Off kit from Clontech: the pTet-Off plasmid, coding for tTA (tet activator); pTREluc, coding for luciferase under the control of the tet activator tTA; pTKHyg, coding for hygromycin resistance; and pTRE2, the cloning plasmid. pTRE HA-E6 was obtained by cloning the Hindll blunt end-BamHI fragment from pHA-E6 S into the EcoRI blunt end-BamHI sites of the pTRE2 vector.

pcDNA3-FADD was kindly provided by Dr. Carl Ware (La Jolla Institute for Allergy and Immunology, La Jolla, CA, USA). pEGFP-1 was purchased form Clontech Laboratories (Mountain View, CA, USA) and a CMV promoter construct was cloned into its multiple cloning site for constitutive expression of GFP.

\section{Cell viability assay}

Following treatment of cells as described below, the incubation medium was removed and exchanged with $80 \mu \mathrm{l}$ of fresh medium. Twenty microliters of MTT was then added ( $5 \mathrm{mg} / \mathrm{ml}$ stock), and cells were incubated at $37^{\circ} \mathrm{C}$ for $3 \mathrm{~h}$. The medium was removed, and $150 \mu$ l of DMSO was added and allowed to incubate for $10 \mathrm{~min}$. The solution was mixed by pipetting, and the absorbance of each well was measured at $490 \mathrm{~nm}$.

\section{Treatment of Cells with TRAIL, TNF, anti-Fas, CHX, Mitomycin C, Ceramide and Z-VAD-FMK}

To measure cell survival following treatment with TRAIL and TNF, HCT116 cells were seeded in a 96-well $\left(2 \times 10^{4}\right.$ cells/well) and allowed to adhere overnight. TRAIL (at the concentrations noted in text and figures) and TNF $(5 \mathrm{ng} / \mathrm{ml})$ were then added in the presence of $\mathrm{CHX}(1-5 \mu \mathrm{g} / \mathrm{ml})$ and the cells were incubated for $16 \mathrm{~h}$ before measuring the number of viable cells by the MTT assay.

To determine cell survival following mitomycin $\mathrm{C}$ and ceramide treatment, HCT116 cells were seeded in a 96-well plate as described above (100 $\mu$ total volume) and allowed to adhere overnight. For mitocmycin $\mathrm{C}$ treatment, fresh media containing the indicated concentrations of the genotoxin was added to the wells, and the cells were incubated for $24 \mathrm{~h}$ before measurement of the number of viable cells by the MTT assay. Before ceramide treatment, spent media was removed and replaced with media supplemented with $2 \%$ serum. Ceramide was then added to the indicated final concentrations, and the cells were incubated for $24 \mathrm{~h}$ before measurement of the number of viable cells by the MTT assay.

To determine whether cell death following TRAIL treatment was caspase dependent, HCT116 cells were treated with $\mathrm{CHX}(5 \mu \mathrm{g} / \mathrm{ml})$ and TRAIL in the presence or absence of Z-VAD-FMK $(50 \mu \mathrm{M})$. Finally, the effect of E6 on the levels of FADD and procaspase 8 were determined by treating $\mathrm{HCT} 116$ cells containing or lacking $\mathrm{E} 6$ with $\mathrm{CHX}(5 \mu \mathrm{g} / \mathrm{ml})$ for the indicated hours.

\section{Transfections}

Transfections (except with siRNA) were carried out using FuGENE VI (Roche Molecular Biochemicals), as directed by the manufacturer. For transient transfections, cells were analyzed $40-48 \mathrm{~h}$ post-transfection. For stable transfections, clones were passaged into selection medium containing G418 $(500 \mu \mathrm{g} / \mathrm{ml}) 72 \mathrm{~h}$ post-transfection. Individual clones were selected, grown and analyzed for protein expression by immunoprecipitation and immunoblotting.

\section{Immunoblotting}

Cells $\left(2 \times 10^{6}\right)$ were lysed in $100 \mu$ l of lysis buffer $(50 \mathrm{mM}$ Tris- $\mathrm{HCl}, \mathrm{pH} 7.5$, $150 \mathrm{mM} \mathrm{NaCl}, 1 \%$ Triton X-100, $1 \mathrm{mM}$ EDTA, 5\% glycerol, $1 \mathrm{mM}$ DTT, $1 \mathrm{mM}$ PMSF) for $10 \mathrm{~min}$ on ice. One tablet of protease inhibitor mixture 
(Roche Applied Science) per $10 \mathrm{ml}$ of lysis buffer was added just before use. The protein concentration in cleared lysates was measured using the Bio-Rad Protein Assay (Bio-Rad).

Lysates ( $40 \mu \mathrm{g}$ total protein/lane) were then subjected to $12 \%$ SDSPAGE and transferred to Immobilon P membranes (Millipore Corp.). After treating the membranes with $5 \%$ nonfat milk in TBST ( $50 \mathrm{mM}$ Tris- $\mathrm{Cl}, \mathrm{pH}$ 7.5, $150 \mathrm{mM} \mathrm{NaCl}, 0.1 \%$ Tween-20), primary antibodies were applied and membranes were incubated for $1 \mathrm{~h}$, with rocking, at room temperature. After washing with TBST, peroxidase-coupled secondary antibodies were added for detection. The membranes were then washed again with TBST following $1 \mathrm{~h}$ of incubation in the secondary antibodies. Detection of the proteins was performed by using the chemiluminescent SuperSignal West Femto or Pico Maximum Sensitivity substrate (Pierce).

\section{Immunoprecipitation}

HCT116 cells $\left(2-5 \times 10^{6}\right)$ were lysed in $500 \mu$ l of the immunoblotting lysis buffer, and cleared lysates were incubated with $2 \mu \mathrm{g}$ of monoclonal anti$\mathrm{HA}$ antibody (Roche Molecular Biochemicals) at $4^{\circ} \mathrm{C}$ for $1 \mathrm{~h}$ with rotation. Protein A/G-agarose slurry $(50 \mu l$ ) (Santa Cruz Biotechnology, Santa Cruz, CA, USA) was added to each lysate, and lysates were incubated for $2 \mathrm{~h}$ at $4^{\circ} \mathrm{C}$. The protein $\mathrm{A} / \mathrm{G}$ slurry was then washed three times with lysis buffer, followed by one wash with high salt buffer $(50 \mathrm{mM}$ Tris- $\mathrm{HCl}, \mathrm{pH} 7.5$, $0.5 \mathrm{M} \mathrm{NaCl}, 0.1 \%$ Nonidet P-40, $1 \mathrm{mM}$ EDTA, $1 \mathrm{mM}$ DTT) and one wash with the same buffer lacking $\mathrm{NaCl}$. The precipitates were fractionated by $12 \%$ SDS-PAGE, and immunoblotting was performed as described above.

\section{Morphological analysis of apoptotic cells}

Cells were seeded on cover slips in a 6-well plate and allowed to incubate overnight. The following day, they were treated with $50 \mathrm{ng} / \mathrm{ml}$ TRAIL plus $\mathrm{CHX}(5 \mu \mathrm{g} / \mathrm{ml})$. After the indicated time points, slides were fixed in a solution of $4 \%$ paraformaldehyde in PBS, then mounted using Vectashield mounting medium with 4',6-diamidino-2-phenylindole (DAPI) (Vector Laboratories Inc. Burlingame, CA, USA). The morphology of these cells was then analyzed by phase-contrast microscopy (Olympus BX50, Japan). The DAPI-stained nuclei were monitored using the UplanFI objective at a magnification of $1000 \times$. The percentage of apoptotic cells was expressed as the percentage of cells exhibiting condensed nuclei and/or nuclei with fragmentations as compared to the total number of nuclei examined. At least 100 nuclei were counted for each determination. Percentages represent and average of three determinations.

\section{Development and use of the Tet-Off system}

HCT116 cells capable of expressing variable amounts of HA-E6, regulated by the dose of drug present in the media, were created using the Tet-Off system (Clontech) according to the manufacturer's protocol with some modifications. ${ }^{29}$ Cultures of these cells were grown in the indicated concentrations of dox for two days before use, and the indicated concentrations of dox were maintained in the media throughout each experiment.

\section{RT-PCR}

The RT-PCR was used to analyze the HA-E6 message in the HCT116 TetOff cell line. cDNA was synthesized by using SuperScript ${ }^{\mathrm{TM}}$ II reverse transcriptase (Invitrogen) and an oligo(dT) primer (Amersham). PCR was then employed to amplify full-length E6 with primers for the $5^{\prime}\left(5^{\prime}\right.$ GCACCAAAAGAGAACTGCAATGT-3) $)^{\prime}$ and $3^{\prime}$ (5'-TGGGTTTCTCTAC
GTGTTCTTGAT-3') end of the sequence, using $1 / 20$ of the total CDNA reaction mixture. Additionally, the Cofilin 1 (CFL1) message was amplified to normalize E6 levels with primers specific for CFL1. To control for possible contamination by genomic DNA, parallel reactions were run using $0.175 \mu \mathrm{g}$ of total RNA in the absence of the reverse transcriptase enzyme.

\section{Targeted silencing of gene expression using siRNA}

Transfection of cells with control siRNA (random sequence) (Dharmacon Research Inc., Lafayette, CO, USA) and FADD siRNA (Santa Cruz Biotechnology) was performed according to the manufacturer's protocol. Cells were seeded in media lacking antibiotics and incubated at $37^{\circ} \mathrm{C}$ overnight. The transfection mixtures were then prepared by adding siRNA to siTransfection Medium (Santa Cruz Biotechnology) in one tube and siTransfection Reagent (Santa Cruz Biotechnology) to siTransfection Medium (Santa Cruz Biotechnology) in another tube and incubating the contents of the tubes at room temperature for $5 \mathrm{~min}$. The amounts of the reagents were calculated based on the values indicated in the protocol and were scaled up or down in proportion to the surface area of the plate. After $5 \mathrm{~min}$, the mixtures were combined and incubated at room temperature for 20 min to facilitate the development of a siRNA-siRNA Transfection Reagent Complex. During this time, the media covering the cells was replaced with fresh media without antibiotics and at the end of the $20 \mathrm{~min}$ incubation, the complex was added to the cells. The cells were then incubated at $37^{\circ} \mathrm{C}$ for $24-30 \mathrm{~h}$.

To verify that SiFADD was reducing the expression of exogenous FADD, the cells were seeded in a six-well plate at a density of $2.5 \times 10^{5}$ cells/well and transfected with siControl or siFADD as described above. Afterward, the cells were transfected with pcDNA3-FADD and pE-1CMVGFP and incubated for $24-48 \mathrm{~h}$ at $37^{\circ} \mathrm{C}$. The expression of FADD and GFP was then analyzed by immunoblot.

To measure the survival of siFADD-expressing cells following treatment with TRAIL, cells were seeded in a 96-well plate at a density of $1.8 \times 10^{4} \mathrm{cells} /$ well and transfected with siControl or siFADD as described above. The cells were then treated with TRAIL $(50 \mathrm{ng} / \mathrm{ml})$ in the presence of $\mathrm{CHX}(5 \mu \mathrm{g} / \mathrm{ml})$ for $16 \mathrm{~h}$ and cell viability was determined by the MTT assay.

\section{Caspase 8, 3 and 2 assays}

Cells were plated into black 96 -well plates at a density of $2 \times 10^{4}$ cells per well and incubated overnight. TRAIL $(50 \mathrm{ng} / \mathrm{ml})$ was then added, along with $\mathrm{CHX}$ ( 1 or $5 \mu \mathrm{g} / \mathrm{ml}$ ) for the times indicated. Caspase activity was then measured using the flourogenic substrate IETD-AMC for caspase 8, DEVD-AMC for caspase 3 and VDVAD-AMC for caspase 2 (Alexis Biochemicals) as described. ${ }^{51}$ Briefly, cells (in a total volume of $40 \mu \mathrm{lmedia} /$ well) were lysed by the addition of $20 \mu \mathrm{l}$ of $3 \times$ lysis buffer (150 mM HEPES, pH 7.4, $450 \mathrm{mM}, \mathrm{NaCl}, 150 \mathrm{mM} \mathrm{KCl}, 1.2 \mathrm{mM}$ EGTA, $1.5 \%$ Nonidet P40, $0.3 \%$ CHAPS, $30 \%$ sucrose, $30 \mathrm{mM}$ DTT, $3 \mathrm{mM}$ PMSF), which included either substrate alone $(150 \mu \mathrm{M})$ or substrate plus inhibitor $(2 \mu \mathrm{g} / \mathrm{ml})$. The inhibitors for caspases 8,3 and 2 were IETD-CHO (BD Pharmingen), DEVD-CHO (Alexis Biochemicals) and VDVAD-CHO (Alexis Biochemicals), respectively. After 2, 4 and $6 \mathrm{~h}$ of incubation for caspases 3 and 8 , and 3 and $6 \mathrm{~h}$ of incubation for caspase 2 , the released fluorochrome was measured with a plate-reading fluorimeter (Flx800, BioTek Instrument Co.) using an excitation of $360 \mathrm{~nm}$ and an emission of $460 \mathrm{~nm}$. The activity in wells treated with the inhibitor was subtracted from the activity in wells lacking the inhibitor. The resulting difference was expressed as a percentage of caspase activity in the untreated parental 
cells. Data from three independent experiments are shown, and error bars represent the standard deviation.

\section{Statistical analysis}

Data were analyzed using the unpaired $t$-test on a GraphPad Prism software package for Windows (GraphPad Software Inc.). A $P$-value of $\leq 0.05$ was considered statistically significant.

\section{Acknowledgements}

This work was supported in part by NIH Grant 1 R01 CA-095461 (PDH), Ruth L. Kirschstein National Service Award Individual Fellowship 1 F31 CA113650-01A1 (TG), and by NIH award 2R25 GM060507-05 (TG). In addition, we thank Dr. Carl Ware (La Jolla Institute for Allergy and Immunology) for the pcDNA-FADD-encoding plasmid.

\section{References}

1. Wiley SR, Schooley K, Smolak PJ, Din WS, Huang CP, Nicholl JK, Sutherland GR, Smith TD, Rauch C, Smith CA and Goodwin RG (1995) Identification and characterization of a new member of the TNF family that induces apoptosis. Immunity 3: 673-682.

2. Ashkenazi A, Pai RC, Fong S, Leung S, Lawrence DA, Marsters SA, Blackie C, Chang L, McMurtrey AE, Hebert A, DeForge L, Koumenis IL, Lewis D, Harris L, Bussiere J, Koeppen H, Shahrokh Z and Schwall RH (1999) Safety and antitumor activity of recombinant soluble Apo2 ligand. J. Clin. Invest. 104: $155-162$.

3. Pan G, O'Rourke K, Chinnaiyan AM, Gentz R, Ebner R, Ni J and Dixit VM (1997) The receptor for the cytotoxic ligand TRAIL. Science 276: 111-113.

4. Pan G, Ni J, Wei YF, Yu G, Gentz R and Dixit VM (1997) An antagonist decoy receptor and a death domain-containing receptor for TRAIL. Science 277: 815-818.

5. Sheridan JP, Marsters SA, Pitti RM, Gurney A, Skubatch M, Baldwin D, Ramakrishnan L, Gray CL, Baker K, Wood WI, Goddard AD, Godowski P and Ashkenazi A (1997) Control of TRAIL-induced apoptosis by a family of signaling and decoy receptors. Science 277: 818-821.

6. Mongkolsapaya J, Grimes JM, Chen N, Xu XN, Stuart DI, Jones EY and Screaton GR (1999) Structure of the TRAIL-DR5 complex reveals mechanisms conferring specificity in apoptotic initiation. Nat. Struct. Biol. 6: 1048-1053.

7. Sprick MR Weigand MA, Rieser E, Rauch CT, Juo P, Blenis J, Krammer PH and Walczak H (2000) FADD/MORT1 and caspase-8 are recruited to TRAIL receptors 1 and 2 and are essential for apoptosis mediated by TRAIL receptor 2. Immunity 12: 599-609.

8. Kischkel FC, Lawrence DA, Chuntharapai A, Schow P, Kim KJ and Ashkenazi A (2000) Apo2L/TRAIL-dependent recruitment of endogenous FADD and caspase-8 to death receptors 4 and 5 . Immunity 12: 611-620.

9. Jeremias I, Herr I, Boehler T and Debatin KM (1998) TRAIL/Apo-2-ligandinduced apoptosis in human T cells. Eur. J. Immunol. 28: 143-152.

10. Kayagaki N, Yamaguchi N, Nakayama M, Kawasaki A, Akiba H, Okumura K and Yagita $H$ (1999) Involvement of TNF-related apoptosis-inducing ligand in human CD4+ T cell-mediated cytotoxicity. J. Immunol. 162: 2639-2647.

11. Fanger NA, Maliszewski CR, Schooley K and Griffith TS (1999) Human dendritic cells mediate cellular apoptosis via tumor necrosis factor-related apoptosis-inducing ligand (TRAIL). J. Exp. Med. 190: 1155-1164.

12. Griffith TS, Wiley SR, Kubin MZ, Sedger LM, Maliszewski CR and Fanger NA (1999) Monocyte-mediated tumoricidal activity via the tumor necrosis factorrelated cytokine, TRAIL. J Exp. Med. 189: 1343-1354.

13. Zamai L, Ahmad M, Bennett IM, Azzoni L, Alnemri ES and Perussia B (1998) Natural killer (NK) cell-mediated cytotoxicity: differential use of TRAIL and Fas ligand by immature and mature primary human NK cells. J. Exp. Med. 188 2375-2380.

14. Sato $\mathrm{K}$, Hida S, Takayanagi $\mathrm{H}$, Yokochi $\mathrm{T}$, Kayagaki $\mathrm{N}$, Takeda $\mathrm{K}$, Yagita $\mathrm{H}$ Okumura K, Tanaka N, Taniguchi T and Ogasawara K (2001) Antiviral response by natural killer cells through TRAIL gene induction by IFN-alpha/ beta. Eur. J. Immunol. 31: 3138-3146.

15. Herbeuval JP, Boasso A, Grivel JC, Hardy AW, Anderson SA, Dolan MJ, Chougnet C, Lifson JD and Shearer GM (2005) TNF-related apoptosis-inducing ligand (TRAIL) in HIV-1-infected patients and its in vitro production by antigenpresenting cells. Blood 105: 2458-2464.

16. Gibellini D, Re MC, Ponti C, Maldini C, Celeghini C, Cappellini A, La Placa M and Zauli G (2001) HIV-1 Tat protects CD4+ Jurkat T lymphoblastoid cells from apoptosis mediated by TNF-related apoptosis-inducing ligand. Cell Immunol. 207: 89-99.

17. Gibellini D, Carla Re M, Ponti C, Vitone F, Bon I, Fabbri G, Grazia Di lasio M and Zauli G (2005) HIV-1 Tat protein concomitantly down-regulates apical caspase-10 and up-regulates c-FLIP in lymphoid T cells: A potential molecular mechanism to escape TRAIL cytotoxicity. J. Cell Physiol. 203: 547-556.

18. Benedict CA, Norris PS, Prigozy TI, Bodmer JL, Mahr JA, Garnett CT, Martinon F, Tschopp J, Gooding LR and Ware CF (2001) Three adenovirus E3 proteins cooperate to evade apoptosis by tumor necrosis factor-related apoptosisinducing ligand receptor-1 and -2. J. Biol. Chem. 276: 3270-3278.

19. Kabsch $\mathrm{K}$ and Alonso $\mathrm{A}$ (2002) The human papillomavirus type $16 \mathrm{E} 5$ protein impairs TRAIL- and FasL-mediated apoptosis in $\mathrm{HaCaT}$ cells by different mechanisms. J. Virol. 76: 12162-12172.

20. Mantovani $F$ and Banks $L$ (2001) The human papillomavirus $E 6$ protein and its contribution to malignant progression. Oncogene 20: 7874-7887.

21. Longworth MS and Laimins LA (2004) Pathogenesis of human papillomaviruses in differentiating epithelia. Microbiol. Mol. Biol. Rev. 68: 362-372.

22. Parkin DM, Bray F, Ferlay J and Pisani $P$ (2001) Estimating the world cancer burden: Globocan 2000. Int. J. Cancer 94: 153-156.

23. Pisani $P$, Bray $F$ and Parkin DM (2002) Estimates of the world-wide prevalence of cancer for 25 sites in the adult population. Int. J. Cancer 97: 72-81.

24. Scheffner M, Werness BA, Huibregtse JM, Levine AJ and Howley PM (1990) The E6 oncoprotein encoded by human papillomavirus types 16 and 18 promotes the degradation of $\mathrm{p53}$. Cell 63: 1129-1136.

25. Werness BA, Levine AJ and Howley PM (1990) Association of human papillomavirus types 16 and 18 E6 proteins with p53. Science 248: 76-79.

26. Thomas M and Banks L (1998) Inhibition of Bak-induced apoptosis by HPV-18 E6. Oncogene 17: 2943-2954.

27. Gross-Mesilaty S, Reinstein E, Bercovich B, Tobias KE, Schwartz AL, Kahana C and Ciechanover A (1998) Basal and human papillomavirus E6 oncoproteininduced degradation of Myc proteins by the ubiquitin pathway. Proc. Natl. Acad. Sci. USA 95: 8058-8063.

28. Filippova M, Song H, Connolly JL, Dermody TS and Duerksen-Hughes PJ (2002) The human papillomavirus 16 E6 protein binds to tumor necrosis factor (TNF) R1 and protects cells from TNF-induced apoptosis. J. Biol. Chem. 277: 21730-21739.

29. Filippova M, Parkhurst $L$ and Duerksen-Hughes PJ (2004) The human papillomavirus 16 E6 protein binds to Fas-associated death domain and protects cells from Fas-triggered apoptosis. J. Biol. Chem. 279: 25729-25744.

30. Hubert P, Giannini SL, Vanderplasschen A, Franzen-Detrooz E, Jacobs N, Boniver $J$ and Delvenne $P$ (2001) Dendritic cells induce the death of human papillomavirus-transformed keratinocytes. FASEB J. 15: 2521-2523.

31. ATCC (2005) CRL-1550, HTB-35. http://www.atcc.org.

32. Almasan A and Ashkenazi A (2003) Apo2L/TRAIL: apoptosis signaling, biology, and potential for cancer therapy. Cytokine Growth Factor Rev. 14: 337-348.

33. Putt KS, Beilman GJ and Hergenrother PJ (2005) Direct Quantitation of Poly(ADP-Ribose) Polymerase (PARP) Activity as a Means to Distinguish Necrotic and Apoptotic Death in Cell and Tissue Samples. Chembiochem 6: 53-55.

34. Ozoren N and El-Deiry WS (2002) Defining characheristics of types I and II apoptotic cells in response to TRAIL. Neoplasia 4: 551-557.

35. Kim S-K Kim K, Kwagh JG, Dicker DT, Herlyn M, Rustgi AK, Chen Y and ElDeiry WS (2004) Death induction by recombinant native TRAIL and its prevention by a caspase 9 inhibitor in primary human esophageal epithelial cells. J. Biol. Chem. 279: 40044-40052.

36. Wagner KW Engels IH and Deveraux QL (2004) Caspase-2 can function upstream of Bid cleavage in the TRAIL apoptosis pathway. J. Biol. Chem. 279: 35047-35052.

37. Benedict CA, Norris PS and Ware CF (2002) To kill or be killed: viral evasion of apoptosis. Nat. Immunology. 3: 1013-1017. 
38. Benedict CA (2003) Viruses and the TNF-related cytokines, and evolving battle. Cytokine Growth Factor Rev. 14: 349-357.

39. Farrow SN, White JH, Martinou I, Raven T, Pun KT, Grinham CJ, Martinou JC and Brown R (1995) Cloning of a bcl-2 homologue by interaction with adenovirus E1B 19 K. Nature 374: 731-733.

40. Perez $D$ and White $E(2000)$ TNF-alpha signals apoptosis through a biddependent conformational change in Bax that is inhibited by E1B 19K. Mol. Cell. 6: 53-63.

41. Hu S, Vincenz C, Buller M and Dixit VM (1997) A novel family of viral death effector domain-containing molecules that inhibit both CD-95- and tumor necrosis factor receptor-1-induced apoptosis. J. Biol. Chem. 272: 9621-9624.

42. Wang GH, Bertin J, Wang Y, Martin DA, Wang J, Tomaselli KJ, Armstrong RC and Cohen JI (1997) Bovine herpesvirus 4 BORFE2 protein inhibits Fasand tumor necrosis factor receptor 1-induced apoptosis and contains death effector domains shared with other gamma-2 herpesviruses. J. Virol. 71: 8928-8932.

43. Skaletskaya A, Bartle LM, Chittenden T, McCormick AL, Mocarski ES and Goldmacher VS (2001) A cytomegalovirus-encoded inhibitor of apoptosis that suppresses caspase-8 activation. Proc. Natl. Acad. Sci. USA 98: 7829-7834.

44. Li H, Bergeron L, Cryns V, Pasternack MS, Zhu H, Shi L, Greenberg A and Yuan J (1997) Activation of caspase-2 in apoptosis. J. Biol. Chem. 272: 21010-21017.
45. Slee EA, Harte MT, Kluck RM, Wolf BB, Casiano CA, Newmeyer DD, Wang HG, Reed JC, Nicholson DW, Alnemri ES, Green DR and Martin SJ (1999) Ordering the cytochrome $c$-initiated caspase cascade: hierarchical activation of caspases-2, -3, -6, -7, -8, and -10 in a caspase-9-dependent manner. J. Cell. Biol. 144: 281-292.

46. Lassus $P$, Opitz-Araya $X$ and Lazebnik $Y$ (2002) Requirement for caspase-2 in stress-induced apoptosis before mitochondrial permeabilization. Science 297: 1352-1354.

47. Guo Y, Srinivasula SM, Druilhe A, Fernandes-Alnemri T and Alnemri ES (2002) Caspase-2 induces apoptosis by releasing proapoptotic proteins from mitochondria. J. Biol. Chem. 277: 13430-13437.

48. Robertson JD, Enoksson M, Suomela M, Zhivotovsky B and Orrenius S (2002) Caspase-2 acts upstream of mitochondria to promote cytochrome $c$ release during etoposide-induced apoptosis. J. Biol. Chem. 277: 29803-29809.

49. Pim D, Collins M and Banks L (1992) Human papillomavirus type 16 E5 gene stimulates the transforming activity of the epidermal growth factor receptor. Oncogene 7: 27-32.

50. Kell B, Jewers RJ, Cason J, Pakarian F, Kaye JN and Best JM (1994) Detection of E5 oncoprotein in human papillomavirus type 16-positive cervical scrapes using antibodies raised to synthetic peptides. J. Gen. Virol. 75 (Part 9): 2451-2456.

51. Carrasco RA, Stamm NB and Patel BK (2003) One-step cellular caspase-3/7 assay. Biotechniques 34: 1064-1067. 